\title{
Os Arquivos Médicos do $A B C$ agora são Arquivos Brasileiros de Ciências da Saúde
}

Ricardo Peres do Souto ${ }^{1}$

A pesar de não estar presente no início da trajetória dos Arquivos Médicos do $A B C$ há trinta anos, imagino um grupo pioneiro de alunos e professores da Faculdade de Medicina do ABC sonhando com um veículo de informação científica que fosse capaz de instigar e divulgar a pesquisa na Instituição. Desde o início romântico, a revista passou por diferentes fases, colhendo sucessos e enfrentando as dificuldades comuns aos periódicos de porte similar. Com a ajuda direta de editores, conselheiros, revisores e outros colaboradores e o suporte de toda a comunidade FMABC, a revista estruturou-se e amadureceu ao longo dos anos. Esses primeiros anos da revista são descritos com mais detalhe pelo Prof. Szulim Ber Zyngier, um de seus principais protagonistas, em editorial na página seguinte.

Tal evolução da revista resultou no presente momento, onde mais uma etapa da história sonhada em 1978 se concretiza, quando os Arquivos Médicos do $A B C$ são renomeados Arquivos Brasileiros de Ciências da Saúde. Ao refletir sobre necessidade e a adequação de se modificar o nome tradicional e estimado, percebo que a mudança já havia sido iniciada anteriormente, no próprio conteúdo da revista. Com o novo título, oficializa-se a ampliação dos temas de interesse, contemplando todas as Ciências da Saúde. Essa tendência já era muito clara, sendo possível citar várias contribuições de enfermagem, fisioterapia, ciências básicas, além da própria medicina. Em especial, a partir de agora a revista deseja atrair produções científicas que envolvam a colaboração de diferentes profissionais e interações entre várias disciplinas, uma vez que esses trabalhos são muito ricos e despertam interesse especial. Além disso, a revista tem mostrado nos últimos anos uma maior capacidade de captar artigos externos. Suponho que tal fenômeno deva ser atribuído ao aumento de sua exposição pela distribuição livre online (http:/ / www.fmabc.br/amabc) e ao ajuste de sua política editorial, com a introdução da revisão por pares para todos os manuscritos submetidos. Com o novo título, a revista também planeja consolidar a ampliação de suas fronteiras geográficas e se apresentar como alternativa real para atender às necessidades de grupos de pesquisa em Ciências da Saúde originários de todo o território brasileiro. Concluindo, espero que o nome escolhido transmita adequadamente o comprometimento do Corpo Editorial em produzir um periódico com maior abrangência e maior alcance, e principalmente, que a reafirmação do escopo amplo seja mais uma atitude a contribuir para sua qualificação científica.

Neste primeiro fascículo dos Arquivos Brasileiros de Ciências da Saúde foi introduzida uma nova seção de Cartas ao Editor. Dessa maneira a revista pretende abrir espaço para contribuições de interesse no ambiente científico que não se originem obrigatoriamente de atividade de pesquisa. A estréia da seção conta com textos de destacados pesquisadores brasileiros, com inserção na comunidade científica internacional, comentando o tema atual e controverso envolvendo a experimentação em animais. A meu ver, trata-se de assunto de extrema importância, que a revista já abordou anteriormente em editorial de um membro do Conselho Científico (Colombari E. Animais em Experimentação: usar ou não usar, será esta a questão? Arq Méd $A B C$ 2007; 32:52). Agradeço especialmente a colaboração do Dr. José Carlos Souza Pinto, membro do Comitê de Ética em Experimentação Animal da FMABC, que muito se empenhou em reunir esse seleto grupo de lideranças científicas do nosso país.

Em seqüência, este fascículo traz nas seções habituais: Serra e colaboradores estudam o perfil epidemiológico de uma das mais importantes causas de perda de visão; Machado Júnior e Dalmaso analisam a resolutividade do sistema público de saúde para os casos de mulheres com exame de Papanicolau positivo; Auad e colaboradores avaliam os benefícios de um programa de exercícios físicos para mulheres com osteoporose; Henriques e colaboradores relatam um caso infreqüente de tumor intestinal produtor de somatostatina; Zanazi Júnior e colaboradores apresentam um caso de queimadura química por álcali e ressaltam as peculiaridades do tratamento em relação às queimaduras térmicas; Serpa Neto e colaboradores discutem os múltiplos fatores que determinam o preocupante avanço da obesidade na sociedade moderna; Formenti e colaboradores revisam a importância da aldosterona no controle cardiovascular considerando os estimulantes achados recentes de novos alvos desse mineralocorticóide, incluindo o próprio sistema nervoso central. 